\title{
Perceptions on Recurrent Drought Incidents by Households in Janamora District, North Gondar Zone, Amhara Region, Ethiopia.
}

\author{
*Mr. Dereje Amene Yimam, ${ }^{* *}$ Dr. Menberu Teshome Zeleke, ***Dr. Pujari Krishnaiah \\ *Lecturer , Department of Development and Environmental Management Studies, College of Social \\ Sciences and Humanities, University of Gondar, Ethiopia \\ ***Assistant Professor, Department of Geography and Environmental Studies, College of Social Sciences and \\ Humanities, University of Gondar, Ethiopia. \\ ***Associate Professor, Department of Geography and Environmental Studies, College of Social Sciences \\ and Humanities, University of Gondar, Ethiopia.
}

\begin{abstract}
Recurring drought is a major challenge in the Drought Prone Area of Janamora in North Ethiopia. Rainfed agriculture is the major income activity of over $91 \%$ of the district's population. The objective of this study was to understand the rural farming community's perception of drought impacts on their livelihood status and their coping strategies at household level. This study was based on both primary and secondary data collected through a survey of 334 farming households and 35 years of precipitation and temperature data retrieved from National Meteorology Agency of Ethiopia. The results elucidated that the mean annual rain fall was $786.2 \mathrm{~mm}$ and variability for years 1979-2013 reaches $27.2 \%$ at Janamora district. The variation of monthly maximum temperature was found to be $\mathrm{CV} \%$ of $\mathbf{1 6 . 2 \%}$ at Janamora district. The results indicated that more than $80 \%$ of farmers believed that temperature in the district had become warmer and over $90 \%$ were of the opinion that rainfall timing had changed, resulting in increased frequency of drought. Their perception conforms to measured precipitation and temperature trends in the district. Thus, the government should design policies aimed at improving these factors.
\end{abstract}

Keywords: Drought, Perception, Likert Scale, Kruskal-Wallis test

\section{INTRODUCTION:}

Beginning in the early 1970s, the horn of Africa was racked by the ravages of hunger. Natural disasters are not new to the region, which historically could count on at least seven major droughts each country, but in the current era it has been increasing, in part due to massive deforestation and the changing pattern of weather (Edmond et al 1992). Although 21 countries in Sub-Saharan Africa experienced a severe drought in 1984/1985, only a handful of these countries suffered from famine. Drought-related famine is the result of several factors, where the lack of precipitation is the first. This means that famine itself cannot be taken as evidence of drought, while it is also not possible to assess the role of societal conditions without knowledge of the extremeness of the precipitation deficits (Conway and Schipper, 2011).

Ethiopia suffers from recurrent drought and famine. In 1984-85, war and drought caused a food crisis during which around one million people died. In 1999-2000, rains failed again, affecting eight million people. Bymid-2003, an insidious combination of sporadic seasonal rains, poverty and HIV/AIDS has conspired to leave over 12 million Ethiopians dependent on relief (Korecha, 2012). Over the past 30 years, Northern Ethiopia has been affected by a number of major drought events, most notably in 1967, 1977, 1984 and 2002. Future climate projections suggest that global warming is likely to favour conditions of the development of droughts in many regions of Ethiopia. Preassessment over changes in low flow characteristics indicate that Northern parts of Ethiopia are most prone to reductions in minimum flow (Kinfe, 1999). Bryant et al. (2000), drought and climate variability studies have shifted the focus of research from the estimation of impacts to the understanding how farmers perceive drought and climate variability; because identification of those drought properties that are of most importance to farmers is vital in their decision making and thereby to propose the types of mitigation strategies. Janamora as part of 
North Ethiopia, drought episodes have been erupted in a matter of months, or gradually creep up on an unsuspecting society over several seasons. It goes unobserved by the public until impacts from the drought have already occurred. Given projections for increasing drought impacts, it is important to inform policy makers on the causes of drought, its impacts, various mitigation responses and possible mitigation measures perceived at local levels in order to alleviate human suffering. Based on the case of farmers in Janamora district of North Ethiopia, this study was made to examine the level of farmers' perception and awareness about drought, the severity of various drought impacts, and various mitigation measures in practice at the household level. The district was selected because of the sensitivity of the farming households in this region to food and water security during times of drought and other pressures.

\section{RESEARCH METHODS:}

\section{Study area description}

Janamora district is among of the 127 district in Amhara regional state of Ethiopia. The district has been grouped amongst the 64 Woredas identified as the most drought prone and food insecure in Amhara Regional State. Based on the 2007 national census conducted by the Central Statistical Agency of Ethiopia (CSA), Janamora district has a total population of 97,835 , an increase of $0.26 \%$ over the 1994 census, of whom 50,587 are men and 47,251 women; 13,057 are urban inhabitants. With an area of 489.67 square kilometers, Janamora has a population density of 132.8 . A total of 23,843 households were counted in this district.

Janamora has a mountainous landscape with an elevation ranging from 1300 to 3200 meters above sea level. Geographically, the district is located between $12^{0}-38^{0} \mathrm{~N}$ longitude and $37^{\circ} \mathrm{E}-38^{0} \mathrm{E}$ latitude. It has three agro-ecological zones, namely, lowland (Kolla) below 1500 masl covers 8\%; Midaltitude (Woina-Dega) 1500-2300 Masl is about $24 \%$ and highland (Dega) above 2300 masl covers $68 \%$ of the district. According to the daily air temperature data collected by North Gondar Agriculture Research Center, the mean monthly temperature at Mekane-Birhan ranges between $5^{\circ} \mathrm{c}$ to $28^{\circ} \mathrm{c}$. A bi-modal nature characterizes rainfall in most parts of the district. The mean annual rainfall of the district is about $1200 \mathrm{~mm}$. approximately in every three years, the district is often subjected to water stress conditions due to erratic nature of rainfall. Therefore, prolonged droughts (i.e., greater than two years duration) or consecutive years of reduced monsoon rainfall can severely threaten the livelihoods of farmers in the area.

\section{Data collection and analysis techniques:}

The data were collected mainly from two main sources; primary and secondary. Some of the tools that were employed to collect primary data include; household Survey using standardized questions, Focus Group Discussion, In-depth interview with key informants, and field observation. Group discussion were held to substantiate and crosschecking the reliability of the output. Accordingly, 2 group discussions were held, each consisting of 8 participants. Participants were purposely selected based on three criteria: (1) settled in the area for $\geq 20$ years, (2) practice agricultural farming as a means of livelihoods for $\geq 20$ years (3) knowledge on long term trends of drought conditions of the district. These criteria also accounted the recalling ability of the farmers back to some years before. Interviews were held for key informants from environmental protection and land administration office of the district.

As it has been known, the questionnaire survey is one of the effective instruments of data collection. Semi-structured questionnaire was employed to collect the data. Both open and close ended questions were employed to gather relevant information pertaining to the study theme. The questionnaire was designed in English but the interviews were conducted in the local language, Amharic. Prior to the survey, the questionnaire was pre-tested with sub-sets of the targeted population (i.e. few farmers from three representative villages) to check the redundancy, missing information, relevancy as well as validity of the questions.

The questionnaire was then modified based on pretest results. The individuals included in pre-test were omitted from the sample. An individual farming household is considered as a primary sampling unit. A multi-stage stratified systematic sampling technique was used to select samples from the target population. The district was divided into three different strata based on agro-ecologies. It is assumed that the different agro-ecologies will influence the farmers' perception of drought impacts, adaptation, and mitigation measures. In the first stage, the villages were selected by probability proportional to size (PPS) sampling technique, and in the second stage households were chosen from selected villages by random walk sampling technique. Sample size determination formula by Akin and Colton was used to calculate minimum sample size. Accordingly, a total of 351 households were surveyed. Considering the population 
proportion in all three strata, 92, 104 and 155 households were selected from Kolla, Woina-Dega and Dega agro-ecologies.

Data were analyzed using descriptive statistics. The data was entered into EpiData 3.1 software and then exported to the statistical package SPSS version 20 for the analyses.

Standardized rainfall anomaly was employed to examine the temporal characteristics and prevalence of drought over the period $1979-2013$.

$$
R F A i=\frac{\mathrm{RFi}-\mathrm{RF} \mu}{\mathrm{RF} \mu} * 100
$$

Where $R F A i$ is rainfall anomaly for $i^{\text {th }}$ year, $R F i$ is annual rainfall for $\mathrm{i}^{\text {th }}$ year and $R F \mu$ is long term mean annual rainfall. Subsequently, inter annual rainfall variability was determined by the coefficient of variation (CV), which is obtained by dividing the standard deviation of the annual rainfall by the average long term rainfall over a given period.

Summated rating scale was used to measure farmers' perception towards drought incidence trends using the guidelines suggested by Likert (1932) with necessary modifications. The perceptions were measured as evaluative perceptions of the respondents on drought incidence trends. This was done with the assumption that evaluative perception reflected their liking or disliking to a great extent and moreover it reflected their judgments on drought incidence trends and perceived effects. A Likert scale was employed to rate each item on a response scale. Respondents were asked to answer each question by rating each item on a 1-to-3 response scale, so that a higher score reflected a higher level of agreement of each item. After entering individual scores, an average or mean score and standard deviation for the whole group for each survey question was calculated. In the case of assigning higher values to stronger agreement, then higher mean scores for each question was translated into levels of agreement for each item, and thus, lower scores reflected participants' disagreement with each item asked.

\section{RESULTS AND DISCUSSION:}

\section{General Profile of Household Respondents}

The mean age of farming households was found to be above 46.3 years. This implies that farming community have immense experiences so that they can easily comprehend climate trends over the area. The average year of farm experiences is 24.64 years. This indicates that under the socio-economic condition of the study area age and experience in farming are related. With longer experience in farming, a wide knowledge, skills and attitudes are gained on the operation and conduct of traditional drought coping strategies and methods of production. So, farmers with longer experience are more conservative and sceptical. It is less likely that farmers with longer farming experience will be ready to accept changes and implement new ideas and techniques of drought coping mechanisms. The overall average household size of the sampled population was 4.8 , which is almost equivalent with the average size of 5 persons per household in the Amhara Regional State. Data on education indicated that $69.2 \%, 22.6 \%$ and $47.5 \%$ respondents had no education, completed their primary education, and secondary education respectively. Agriculture is the main income sources of $96.4 \%$ respondents. The average annual household income of each respondent is $\$ 1454$.

To comprehend households' perception towards drought incidents in Janamora district, households were asked to specify what they had well-known concerning long term variations in temperature and precipitation. The results of this analysis are presented below. Farmers' attitude towards drought incidents was assessed in terms of their evaluative perceptions using a scale developed for the purpose of this study.

Table 1. Farmers' perception (\%) on drought in Janamora district, north western Ethiopia

\begin{tabular}{|l|l|l|l|}
\hline \multirow{2}{*}{ Attitude statements } & \multicolumn{4}{l|}{ Decision by the household } \\
\cline { 2 - 4 } & Agree & Neutral & Disagree \\
\hline Drought is bad & 334 & - & - \\
\hline Drought incident decreases land productivity & 233 & 84 & 17 \\
\hline Prevalence of drought is very common & 284 & 5 & 45 \\
\hline Livestock are vulnerable to drought & 312 & 12 & 10 \\
\hline Outbreak of crop and animal diseases are very common & 318 & 2 & 14 \\
\hline Drought will continue affecting farmland in the future & 247 & - & 87 \\
\hline
\end{tabular}


The value of the scale for the positive statements of evaluative perception on drought incidents were assigned 3, 2, 1 for agree, neutral, and disagree respectively, whereas the negative statements were assigned to the reverse values. Post administration reliability test for all the items considered to assess attitude on drought incidents resulted in the standardized alpha of 0.8015 , which is in the acceptable range to distinguish respondents. The value above this average value was taken as a domain to classify perceptions of households whether they agree or disagree on each item. The scale values were multiplied by the respective frequency values and summed up the data series and divided to total frequency values. The value of Likert scale is found to be 2.78. Therefore respondents had common perceptions to drought incidents in terms of its prevalence, effect on livestock and crop productivity, and its future implication.

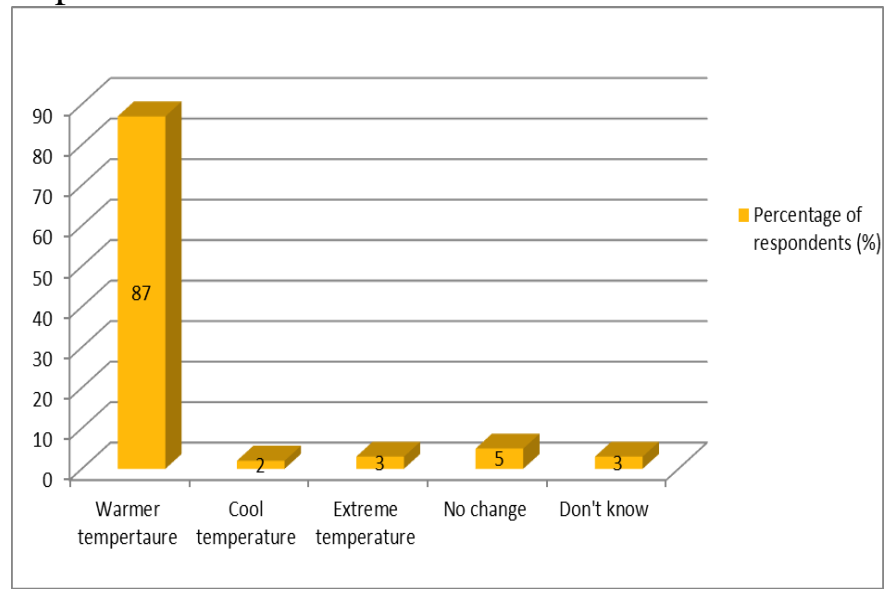

Figure 1. Farming households' perceived changes of temperature in the study district.

About $87 \%$ of the farmers interviewed perceived long-term increment of warmer temperature. Only $2 \%$ noticed the contrary, an increment of cool temperature. About 5\% have not noticed any changes in the temperature. It was very common for FGD participants to come easily to a consensus that there is an overall increase in temperatures (increase in hotness and reduction in coldness). Studies in several other developing countries indicate that most farmers perceive temperatures to have become warmer and rainfall reduced over the past decades (Deressa et al., 2011).

3) Households' perception on precipitation trends

The type of rainfall received in Janamora district is bi-modal which means dominantly they received 'Bulg' and 'Kiremt' rainy seasons.
2) Households' perceptions on temperature trends :

Majority of the farmers $(87 \%)$ interviewed believe that temperature has become warmer (Figure-4.1). The climatic data of the district showed the weather was warm from 1979 to 2013 but became relatively cooler during 1996, and 2002. Their perception slightly differed from the recorded data probably because the cooling effect of 1996 and 2002 is not significant enough for them to notice. Households' perception of temperature in the district is consistent with farmers' perception in other African countries as reported by Maddison (2007) and IFPRI (2008).

A key informant in his 80 s pointed out that: "...when I was young, I used to dress a blanket and a leather the whole day during Winter and Spring seasons when I went to keep livestock but now a day our children were nothing because of hotness..."

As indicated from the figure below, about $68 \%$ of the respondents said that rainfall is highly variable for the past 20 to 30 years. Respondents observed changes in rainfall patterns over the past 20 years, Respondents were more aware of frequent drought incidents related to the rainy season than other seasons. About $8 \%$ of the respondents noticed a decrease in the amount of rainfall or a shorter rainy season and $6 \%$ of the respondents noticed an increase in the amount of rainfall or a longer rainy season.

A 66 years old farmer explained that: “...there were clear cut differences in the seasons when I were young but nowadays there is a lot of mix, it gets cold when it is not supposed to and gets hot when it wants, rains are no longer good... Seasons are confusing nowadays..."

The other interviewed farmer aged 72 explained that "...The set of rains that started from late March was used for tilling and planting. But nowadays, it is no longer there. Rain nowadays just comes in a jumbled manner, whenever it wants and goes at anytime. Sometimes it rains other times instead of the rains reducing and stopping, it continues and sometimes falls heavily destroying crops that were matured and supposed to be harvested. It is difficult to predict the rains' character nowadays..." 


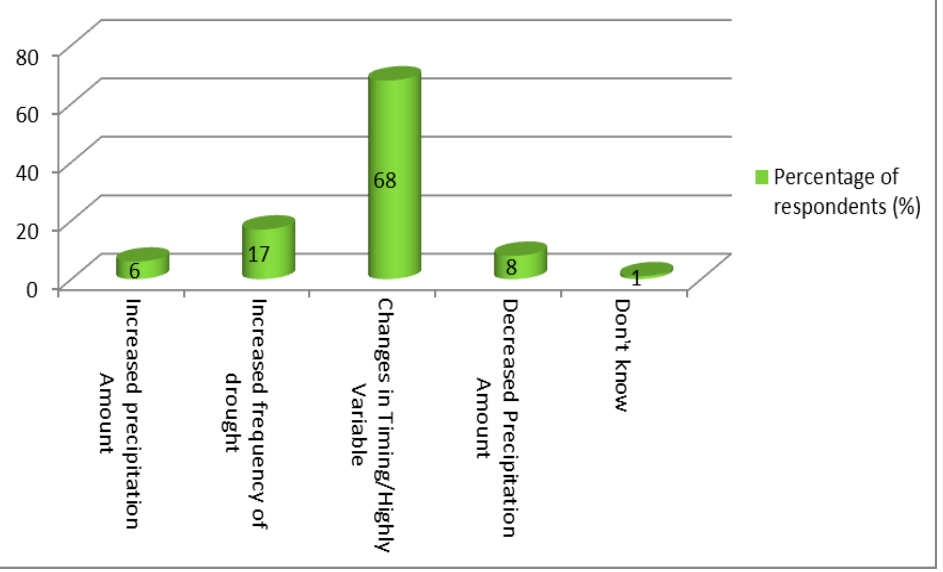

Figure 2. Farming households' perceived changes of rainfall trends in the study district

Table2. Perceptions of farming households on the effects of drought related hazards in the past 15 years

\begin{tabular}{|l|l|l|l|l|l|}
\hline Items & $\mathrm{N}$ & Min. & Max & Mean & Std. De \\
\hline Frequency of drought for the last 15 years & 334 & 2 & 6 & 4.13 & 1.369 \\
\hline Frequency of hail for the last 15 years & 334 & 2 & 7 & 4.52 & 1.676 \\
\hline Frequency of flood for the last 15 years & 334 & 1 & 4 & 2.61 & 1.154 \\
\hline $\begin{array}{l}\text { Frequency of drought related livestock epidemics for the } \\
\text { last 15 years }\end{array}$ & 334 & 1 & 4 & 2.56 & 1.150 \\
\hline $\begin{array}{l}\text { Frequency of drought related crop infestation for the last } \\
15 \text { years }\end{array}$ & 334 & 1 & 4 & 2.40 & 1.112 \\
\hline $\begin{array}{l}\text { Frequency of drought related epidemic disease for the } \\
\text { last 15 years }\end{array}$ & 334 & 1 & 4 & 2.46 & 1.116 \\
\hline $\begin{array}{l}\text { Frequency of drought related crop harvest failure for the } \\
\text { last 15 years }\end{array}$ & 334 & & & & \\
\hline
\end{tabular}

Source: Field survey 2016

As it can be seen from the table above, drought conditions were more rampant than floods over the past 20 years.

FGD was held to substantiate the survey study. Accordingly, FGD participants were asked whether they noticed changes in their environments. Participants reported that the temperature is higher, spread of agricultural pests and weeds on crop land; erratic rain; delayed rainfall; less clearly defined seasons (rains sometimes arrive a month late or finish early, rains quickly gave way to sun or dry periods during the rainy season. FGD participants believed that the vagaries of the climate are a sign of divine anger, "as there are many sinners in our midst and God is trying to punish us with serious consequences".

Table 3. Farming households" perception of various socioeconomic impacts in Janamora district (asymptotic significance values, $n=148$ ).

\begin{tabular}{|l|l|l|l|l|l|}
\hline & $\begin{array}{l}\text { Agro-ecologies } \\
\text { strata }\end{array}$ & $\begin{array}{l}\text { Land holding } \\
\text { size }\end{array}$ & $\begin{array}{l}\text { Income of } \\
\text { HH }\end{array}$ & Education & $\begin{array}{l}\text { Farming } \\
\text { experience }\end{array}$ \\
\hline Caused food scarcity & 0.43 & 0.78 & 0.74 & 0.64 & 0.79 \\
\hline $\begin{array}{l}\text { Caused population } \\
\text { migration }\end{array}$ & 0.66 & 0.82 & 0.56 & 0.51 & 0.64 \\
\hline Caused malnutrition in reduction in & 0.92 & 0.74 & $0.02^{*}$ & 0.91 & 0.58 \\
\hline $\begin{array}{l}\text { Caused } \\
\text { household income }\end{array}$ & 0.56 & 0.18 & 0.67 & 0.71 \\
\hline Affected on health & 0.87 & 0.36 & 0.92 & 0.37 & 0.18 \\
\hline $\begin{array}{l}\text { Caused farmers suicide } \\
\text { Affected schooling of } \\
\text { children }\end{array}$ & 0.37 & 0.71 & 0.84 & 0.18 & 0.44 \\
\hline
\end{tabular}




\begin{tabular}{|l|l|l|l|l|l|}
\hline Limited food preferences & 0.82 & 0.72 & 0.49 & 0.77 & 0.68 \\
\hline $\begin{array}{l}\text { Threatened household food } \\
\text { security }\end{array}$ & 0.39 & 0.85 & 0.76 & 0.83 & 0.94 \\
\hline Caused unemployment & 0.48 & 0.36 & 0.16 & 0.42 & 0.28 \\
\hline Caused hopelessness & 0.53 & 0.18 & 0.52 & 0.47 & 0.88 \\
\hline $\begin{array}{l}\text { Caused conflicts for water } \\
\text { in society }\end{array}$ & 0.69 & 0.33 & 0.74 & 0.81 & $0.01^{*}$ \\
\hline $\begin{array}{l}\text { Reduction in spending on } \\
\text { festivals }\end{array}$ & 0.55 & 0.19 & 0.63 & 0.56 & 0.38 \\
\hline
\end{tabular}

*Kruskal-Wallis H-test significant at 5\% significance level

Table 2 gives the results of the nonparametric statistical tests of Kruskal-Wallis H-test values for perceived severity of drought impacts against different category of respondents. There was a significant difference observed in malnutrition caused effects of drought based on income groups with poorer farmers affected the most. A significant difference was observed in perception of schooling of children in the society due to drought based on farmers' income level. Poorer farmers do not want to send their children to school, because they couldn't afford schooling expenses during drought incidence periods. A significant difference was also observed in perception of conflicts for water in the society due to drought based on farmers' education level. Less educated farmers said that drought driven water scarcity caused conflicts in the society. Similar cases were reported in drought affected rural Ethiopia.

Table 4. Perception to Changes in Temperature and Precipitation (as a \% of respondents)

\begin{tabular}{|c|c|c|c|c|c|c|c|c|c|c|}
\hline \multirow[t]{2}{*}{$\begin{array}{l}\text { Households } \\
\text { perception }\end{array}$} & \multicolumn{4}{|c|}{$\begin{array}{l}\text { Perception by irrigation access ( as } \\
\text { a \% of respondents) }\end{array}$} & \multicolumn{2}{|c|}{$\begin{array}{l}\begin{array}{l}\text { Perception by } \\
\text { level }\end{array} \\
\text { education ( as } \\
\text { a \% of } \\
\text { respondents) }\end{array}$} & \multicolumn{2}{|c|}{$\begin{array}{l}\text { Perception } \\
\text { by farming } \\
\text { experiences ( } \\
\text { as a \% of } \\
\text { respondents) }\end{array}$} & \multicolumn{2}{|c|}{$\begin{array}{l}\text { Perception } \\
\text { by extension } \\
\text { services ( as } \\
\text { a \% \% of } \\
\text { respondents } \\
\text { ) }\end{array}$} \\
\hline & $\begin{array}{l}\% \text { of } \\
\text { respon } \\
\text { dents }\end{array}$ & $\begin{array}{ll}< & 25 \\
\text { yrs } & \end{array}$ & $\begin{array}{l}{[25-65} \\
\text { yrs }]\end{array}$ & $\begin{array}{l}\geq 65 \\
\text { yrs. }\end{array}$ & $<10$ & $\geq 10$ & $\begin{array}{l}1-10 \\
\text { yrs. }\end{array}$ & $\begin{array}{l}\geq 10 \\
\text { yrs. }\end{array}$ & $\begin{array}{l}1-10 \\
\text { kms }\end{array}$ & $\begin{array}{l}\geq 10 \\
\text { kms }\end{array}$ \\
\hline $\begin{array}{l}\text { Increases in } \\
\text { temperature }\end{array}$ & 85 & 22 & 64 & 15 & 51 & 4 & 12 & 33 & 28 & 27 \\
\hline $\begin{array}{l}\text { Decreases in } \\
\text { temperature }\end{array}$ & 0 & 0 & 0 & 0 & 0 & 0 & 0 & 0 & 0 & 0 \\
\hline $\begin{array}{l}\text { Variations in } \\
\text { temperature }\end{array}$ & 15 & 12 & 18 & 4 & 33 & 1 & 11 & 23 & 16 & 18 \\
\hline $\begin{array}{l}\text { Increases in } \\
\text { precipitation }\end{array}$ & 0 & 0 & 0 & 0 & 0 & 0 & 0 & 0 & 0 & 0 \\
\hline $\begin{array}{l}\text { Decreases in } \\
\text { precipitation }\end{array}$ & 82 & 18 & 53 & \begin{tabular}{|l|}
11 \\
\end{tabular} & 79 & 3 & 67 & 15 & 64 & 19 \\
\hline $\begin{array}{ll}\text { Changes in } \\
\text { timing of } \\
\text { precipitation }\end{array}$ & 68 & 10 & 49 & 9 & 65 & 3 & 57 & 11 & 26 & 42 \\
\hline $\begin{array}{ll}\text { Increases } & \text { in } \\
\text { frequencies } & \text { of } \\
\text { drought } & \\
\end{array}$ & 81 & 22 & 47 & 10 & 77 & 4 & 23 & 59 & 43 & 38 \\
\hline $\begin{array}{l}\text { Changes in } \\
\text { precipitation } \\
\text { patterns }\end{array}$ & 44 & 8 & 30 & 6 & 40 & 4 & 26 & 18 & 14 & 30 \\
\hline
\end{tabular}


Table 4 gives the results of the nonparametric statistical tests (asymptotic significance) values for perceived severity of drought impacts against various respondent groups. There was a significant difference observed in spending on festivals based on income groups with poorer farmers affected the most. Also, farmers from low income groups reported that their expenses on wedding ceremonies were reduced or ceremonies were postponed due to drought. A significant difference was observed in perception of conflicts for water in the society due to drought based on farmers' education level. Farmers from frequent and severe drought affected areas believed that drought was one of the major causes of suicidal tendencies of farmers due to less income and indebtedness with growing interest. Due to reduced income and social status farmers become mentally depressed, which ultimately ends in suicide.

Farmers' perceptions of climate change have been classified according to their years of experience and their level of education. The responses of farmers having less than 15 years, between 15 and 30 years, and 30 or more years of experience had been identified. Pertaining to the level of education, three categories had been distinguished; i.e no formal education, primary education and above secondary education. Using the Kruskal-Wallis test, this study assessed if the perceptions of households on drought according their farming experience and level of education differed significantly. The results show that a slightly higher proportion of farmers with more than 30 years of experience claimed that temperature is increasing and rainfall is decreasing, and noted change in the frequency of droughts and floods. Farmers with more than 30 years of experience are also less likely to claim no change in temperature and no change in rainfall. However, the Kruskal-Wallis test indicated that the views between experienced and inexperienced farmers are statistically not significant. The results also indicated that there is statistically no difference between the views of the educated and less-educated farmers.

Table 5. Results of the seemingly unrelated biprobit model of farming households' perception of change in temperature and precipitation, Janamora district

\begin{tabular}{|l|l|l|}
\hline & $\begin{array}{l}\text { Perceive change in } \\
\text { Temperature }\end{array}$ & Perceive change in precipitation \\
\hline Education & -0.0049 & $-0.0371^{* * *}$ \\
\hline Farming Experience & $0.0136^{*}$ & 0.0048 \\
\hline Access to Extension services & $0.3361^{* *}$ & 0.2271 \\
\hline Access to Irrigation & $-0.5917^{* *}$ & $-0.7279^{* *}$ \\
\hline Log likelihood: -124.0148 & & \\
\hline Number of Observations: 148 & & \\
\hline Athrho: $0.7047^{* * *}$ & & \\
\hline Rho: 0.6784 & & \\
\hline
\end{tabular}

*Kruskal-WallisH-test significant at 5\% significance level.

$* * *$ Significant at $1 \%$ level; ** significant at $5 \%$ level; * significant at $10 \%$ level.

\section{CONCLUSION AND RECOMMENDATIONS:}

Given the fact that the study area is highly dependent on the agricultural sector for income and food security, irregular precipitation would adversely affect the lives of the majority of the population. Farmers' perceptions of climatic variability are in line with climatic data records. Indeed, farmers in Janamora district of North West Ethiopia are able to recognize that temperatures have increased and there has been a fluctuation in the volume of rainfall. Farmers with access to extension services are likely to perceive changes in the climate because extension services provide information about climate and weather. Having access to water for irrigation increases the resilience of farmers to climate variability; therefore, they do not need to pay as much attention to changes in the patterns of rainfall and temperature. With more experience, farmers are more likely to perceive change in temperature. Although farmers are well aware of climatic changes, few seem to take steps to adjust their farming activities. Only approximately 30 percent of farmers have adjusted their farming practices to account for the impacts of climate change.

The main mitigation measures of farmers in Janamora district are switching crops, changing crop varieties, changing planting dates, increasing irrigation, building water-harvesting schemes, changing the amount of land under cultivation, and buying livestock feed supplements. Government policies should therefore ensure that farmers have access to affordable credit to increase their ability 
and flexibility to change production strategies in response to the forecasted climate conditions. Because access to water for irrigation increases the resilience of farmers to climate variability, irrigation investment needs should be reconsidered to allow farmers increased water control to counteract adverse impacts from climate variability and change. Further studies are required to be carried out to establish other drought characteristics such as extreme rainfall, rain days, and other climate change parameters for this district to verify whether the significant trend has occurred and also to establish a correlation between temperature and extreme rainfall.

\section{REFERENCES :}

[1] Bryant, R.C., B. Smit, M. Brklacich, R.T. Johnston, J. Smithers, Q. Chiotti, and B. Singh. 2000. Adaptation in Canadian agriculture to climatic variability and change. Climatic Change 45:181-201.

[2] Deressa, T. T., R. M. Hassan, and C. Ringler, (2008) measuring Ethiopian Farmers' Vulnerability to Climate Change across Regional States, IFPRI Discussion Paper No. 806, http://www.ifpri.org/pubs/dp/ifpridp00806.asp (Washington, DC: IFPRI, 2008).

[3] Korecha, D. and A. Sorteberg (2012). Classification of Ethiopian Rainfall into Homogeneous Regions. Submitted to International Journal of Climatology.

[4] Likert, R.A. (1932). A Technique of Measurement of Attitude, Archives of Psychology, 140, pp. 44-53.

[5] Maddison, D. (2006). The Perception of and Adaptation to Climate Change in Africa. Policy Research Working Paper 4308. University of Pretoria: Centre for Environmental, economics and Policy in Africa. Mertz, "Adaptation to Climate", supra, note 14

[6] McKee, T. B.; N. J. Doesken; and J. Kleist. 1993. "Drought monitoring with multiple time scales." Proceedings of the Ninth Conference on Applied Climatology; pp. 233-236. American Meteorological Society, Boston 